\section{Contemporaneidade e saúde}

\author{
Contemporaneity and health
}

Contemporaneidad y salud

\begin{abstract}
MUDANÇAS SOCIAIS CONTEMPORÂNEAS E SAÚDE: ESTUDO SOBRE TEORIA SOCIAL E SAÚDE PÚBLICA NO BRASIL. Ianni AMZ. São Paulo: Hucitec Editora; 2018. 384 p. ISBN: 978-85-8404-159-6.
\end{abstract}

doi: 10.1590/0102-311X00226620

Nos dias de hoje, com a abundância de fontes informacionais, esta obra de Áurea Ianni 1, pesquisadora e professora (re)conhecida no campo da Saúde Pública brasileira, é mais que mais uma fonte, mas transforma-se em necessidade premente de leitura para as pessoas interessadas em compreender o papel político e intelectual das Ciências Humanas e Sociais em Saúde (CHSS). Deve ser uma obra de referência para todos que desejam repensar seus papéis e se envolverem em uma nova "atitude práxica", na qual se sabe o espaço social que as ciências humanas e sociais ocupam no campo da saúde.

A principal preocupação de Ianni é a discussão sobre a teoria, as práticas e a política nesse campo, visando ao esgotamento das capacidades explicativas das CHSS. Estamos vivendo um momento de novos paradigmas e do nascimento de uma nova prática científica, queiramos ou não, e precisaremos de novos arcabouços teóricos capazes de responder ou fazer novas perguntas e dialogar com as novas técnicas que surgem nesta nova Era. O mundo real é dissonante das nossas antigas formulações teóricas, e o mundo do capitalismo tardio nos contradiz a revezes.

Destarte, Ianni atualiza todas as questões empíricas colocadas pela modernidade utilizando Ulrich Beck e nos guia, de maneira reflexiva, pelo campo do conhecimento teórico epistemológico e a explicação do real. O que é o mundo moderno, o que significa a sociedade de risco e a objetivação são pontos centrais analisados no primeiro capítulo de seu livro. Esses conceitos são explicados de uma maneira bastante clara e precisa, de forma que os leitores neófitos não se percam na linha de pensamento da autora. É um texto altamente didático, professoral, exatamente como toda a obra de Ianni. Além disso, ensina ao leitor como se pensa em consonância com uma linha filosófica, atitude bem pouco usada nos dias de hoje, mas altamente necessária para o pensamento acadêmico.

É um livro moderno, tanto na forma como no estilo.

A prática de "perguntar" durante suas explicações no livro lembra até mesmo uma prática socrática, desta forma, a autora conversa constantemente com o leitor, como se nos explicasse um fato, uma história, "um causo", para logo depois nos animar a pensar em outras hipóteses.

A autora, a partir do segundo capítulo, faz um histórico do papel central da Saúde Pública e Coletiva na história sobre os questionamentos entre o natural-biológico-social. Com uma ri- 
queza argumentativa, nos coloca como coautores de sua obra, considerando sempre a importância do rigor metodológico nas pesquisas em saúde, bem como a compreensão de que em nossa "sociedade de risco" estamos vislumbrando o fracasso dos tratamentos médicos, da racionalidade científica e da governança. Ela aponta que estamos em um momento no qual as incertezas fabricadas, os problemas causados pela resolução ineficiente, a "irresponsabilidade organizada" e a potencialização e multiplicação dos riscos, tudo deve nos levar a novas formas de pensar, ou seja, ao encontro da "sociedade reflexiva".

Dessa forma, novos pactos, acordos, regras e institucionalidades serão necessários. Com certeza essas "novidades" colocaram "em cheque a estrutura sobre a qual a sociedade se movimenta", propondo a visibilidade dos riscos, a despolitização dos saberes e a construção de redes. A perspectiva científica deve considerar que o método científico é igual para todos, portanto, a forma de se pensar em Saúde Pública e Coletiva não difere das demais áreas de conhecimento. As pesquisas nessa área devem se preocupar, neste momento, em retomar o vigor da origem do campo no Brasil e retomar as discussões sobre seus métodos e o compromisso das Ciências Sociais com a saúde.

$\mathrm{Na}$ segunda parte, Ianni faz um resgate histórico desde o aparecimento das Ciências Sociais nas escolas médicas, bem como a importância deste pensamento para a saúde e a política brasileiras. Analisa também os cinco congressos brasileiros de epidemiologia, considerando os marcos teóricos da área e sua relação com os conceitos de biológico e social. Elenca os principais desafios da Saúde Pública e Coletiva, a complexa relação entre o natural e o social, o biologicismo, a compreensão do campo como teórico e prático, as mudanças biotecnológicas e ambientais. Em suma, a autora pensa a saúde como um "campo social, tanto pelo tipo de saberes e práticas que envolve, quanto pela implementação de políticas, estratégias e de gestão pública” (p. 132).
Na terceira parte do livro, Ianni analisa a biomedicina e a Saúde Pública e Coletiva. O foco central da autora é a forma pela qual o corpo biológico ganha novos olhares a partir da 2ạ Guerra Mundial, por meio da articulação entre biologia medicina, ciência, inovação, tecnologia, informação, biodiversidade e rotinas. Discorre sobre as diferentes formas de se pesquisar e observar o corpo humano. Isso a leva a enfatizar a grande importância da Saúde Pública e Coletiva, pois ela "pode, nesse sentido, ser considerada, a um só tempo, um campo de conhecimento e de práticas, uma tecnologia, uma ação social do homem sobre as populações diversas - as humanas e as da 'natureza': animais, vegetais, viróticas, bacteriológicas. A saúde vincula homens e ambientes, natureza e sociedade" (p. 222).

Nessa linha de pensamento, Ianni faz uma análise sobre a iatrogenia e sobre a imprevisibilidade, incontrolabilidade e insegurança para se manejar ou destruir as bactérias (e outros microrganismos), a despeito das várias gerações de antibióticos criadas. Enfatiza que o problema real nunca foi biológico: "nesse sentido, cabe à própria Saúde Pública/Coletiva redefinir seus objetos, $e$ reinstituir o pacto sanitário, que deve estar orientado por uma política consistente de biodiversidade e biossegurança" (p. 263).

Antes de concluirmos, queremos apontar dois conceitos centrais neste livro: primo, o conceito de ética, pois ele nos remete à ideia de que toda natureza é humana e toda doença ainda é resultado da dupla vulnerabilidade, uma devida ao aumento de enfermidades que ocorrem devido ao desenvolvimento das sociedades, e outra vulnerabilidade por causa do encobrimento da permanência das doenças que acometem as pessoas mais pobres e desfavorecidas.

Secondo, a subpolítica é um outro conceito que nos auxiliará a compreender como a medicina, uma arte técnica no Brasil, conseguiu ser inserida na política, mais ainda, quais os resultados para o indivíduo, os grupos populacionais e o meio desta inserção. 
Todas essas questões apresentadas no livro desaguam no conceito de vulnerabilidade, chave para que consigamos reestabelecer novos paradigmas para as relações entre os recursos da natureza e os modos de vida, as judicializações, os desafios da novas teorias e práticas da Saúde Pública e Coletiva, em um momento histórico que demanda uma necessidade visceral de empregarmos a bioética de permeio a nossas ações. Seguramente, esta obra contribui para essa possibilidade ética.

Maria Inez Montagner 1

Miguel Ângelo Montagner 1

1 Universidade de Brasília, Ceilândia, Brasil. montagner@hotmail.com

\section{Colaboradores}

Todos os autores participaram da redação do texto.

\section{Informações adicionais}

ORCID: Maria Inez Montagner (0000-0003-08717826); Miguel Ângelo Montagner (0000-00019901-0871).

1. Ianni AMZ. Mudanças sociais contemporâneas e saúde: estudo sobre teoria social e saúde pública. São Paulo: Hucitec Editora; 2018. 